\title{
A Study of Mechanical Properties of Polymer Composite Membranes with Various Ionic Liquids at Elevated Temperatures
}

\author{
Einars SPRUGIS ${ }^{1 *}$, Guntars VAIVARS ${ }^{1}$, Remo MERIJS MERI ${ }^{2}$ \\ ${ }^{1}$ University of Latvia, Institute of Sopid State Physics, Kengaraga 8, LV-1063, Riga, Latvia \\ ${ }^{2}$ Riga Technical University, Institute of Polymer Materials, Paula Valdena 3, LV-1048, Riga, Latvia \\ crossref http://dx.doi.org/10.5755/j01.ms.25.1.18933
}

Received 31 August 2017; accepted 18 February 2018

\begin{abstract}
Ionic liquid/sulphonated poly(ether ether ketone) composite membranes were prepared using following ionic liquids: 1,2,3-trimethylimidazolium dimethylphosphate, 1-hexyl-3-methylimidazolium dimethylphosphate, 1-dodecyl-3methylimidazolium dimethylphosphate. For each ionic liquid/polymer pair 4 composite membranes were prepared with $10 \mathrm{wt} . \%, 20 \mathrm{wt} . \%, 30 \mathrm{wt} . \%, 40 \mathrm{wt} . \%$ ionic liquid content. Membranes were analyzed using strain-stress testing at various elevated temperatures up to $150{ }^{\circ} \mathrm{C}$. Impact of temperature, ionic liquid content in membrane and structure of ionic liquids on mechanical properties of composite membrane were evaluated. It was found that temperature and ionic liquid content had highest impact on mechanical properties of composite membranes.

Keywords: mechanical properties, proton exchange membrane, fuel cell, ionic liquid.
\end{abstract}

\section{INTRODUCTION}

The topic of clean energy and diversification of its sources is only going to increase in importance considering current knowledge about human impact on climate change [1]. In near future fuel cells (FCs) may play important role in this regard. FCs are electrochemical devices that are able to convert chemical energy from various fuels to electrical energy. If hydrogen is used as a fuel, which is most often the case, no harmful emissions are created during operation of FC [2]. There are several types of FCs, suitable for various workloads. Proton exchange membrane fuel cells (PEMFCs) are among the most researched FCs due to their properties that fit the need of automotive as well as other industries: i) safety - electrolyte in PEMFCs is in solid state, ii) simpler structure due to relatively low operating temperature of PEMFCs (below $200{ }^{\circ} \mathrm{C}$ ), iii) quick startup time [2-4].

Currently perfluorocarbon-based polymer (e.g. Nafion ${ }^{\circledR}$ ) is the electrolyte material of choice in commercial PEMFCs. However, it has several major drawbacks such as low conductivity at low humidity levels and high cost $[3,4]$. Amongst proposed alternatives, sulfonated poly(ether ether ketone) (SPEEK) stands out since it have simple preparation procedure, and good thermal and chemical stability [4]. Both SPEEK as well as Nafion structures contain groups of sulphonic acid. In the hydrated state clusters of water molecules are formed around these groups, which in turn form proton conducting channels $[5,6]$. The consequence is that pristine SPEEK is a dielectric at dehydrated state [7] and isn't suitable for use in high temperature (HT) PEMFCs. Operating PEMFCs in HT range $\left(100-200{ }^{\circ} \mathrm{C}\right)$ have several advantages: higher tolerance to impurities in fuel, simpler heat management system, use of cheaper catalysts [7, 8]. Extensive research has been carried out on various PEM materials and their composites that would enable HT and/or anhydrous operation of PEMFC. This includes modifying polymers by crosslinking, blending, addition of inorganic oxides, clays, acids $[2,6,9,10]$, ionic liquids (ILs) [11-13]. ILs are low melting salts with many useful properties such as high ionic conductivity, low vapor pressure and synthetic flexibility, meaning that their structure (and thus properties) can be easily "adjusted" to fit many different use cases [14]. Thereby ILs are good candidates for substituting water as an essential component for proton conducting in HT PEMFCs in anhydrous conditions. Several key properties have been successfully improved by incorporating ILs in SPEEK membranes, including thermal stability and proton conductivity $[11,15]$. IL/SPEEK composites are also paving the way to a new types of composite membranes by including additional components in addition to ILs, and opening wide variety of possibilities for further enhancement of PEM properties [13]. However, it is well known that ILs have plasticizer effect when incorporated in polymer matrix [16]. It is an undesirable trait for PEM and leads to degradation of the mechanical properties $[2,17,18]$. In this study our aim was to test selection of composite membranes containing various ILs with different concentrations in a wide range of elevated temperatures and to observe the effect that these parameters have on the mechanical properties of composite membrane.

\section{EXPERIMENTAL DETAILS}

SPEEK (Fig. 1) was synthesized using following procedure. PEEK (Sigma-Aldrich) in pellet form was dissolved in concentrated sulfuric acid (95-97\%, SigmaAldrich) and after reaction time for $5 \mathrm{~h}$ at $60^{\circ} \mathrm{C}$ the solution was poured into an excess of ice cold deionized water. The resulting precipitate was washed with deionized water until value of $\mathrm{pH}$ reached 7 and dried in an oven at $60^{\circ} \mathrm{C}$ for $24 \mathrm{~h}$

${ }^{*}$ Corresponding author. Tel.: +371-29-387662.

E-mail address: einars8@gmail.com (E. Spurgis) 
and at $100{ }^{\circ} \mathrm{C}$ for $24 \mathrm{~h}$. Titration method [19] was used for determination of the degree of sulfonation (DS) of SPEEK. DS was determined to be equal to 0.8 .

3 different ILs (Fig. 1) were synthesized in-house by following methodology described elsewhere [20]. ILs then were used for preparation of composite membranes. In general, $0.5 \mathrm{~g}$ of SPEEK was dissolved in $20 \mathrm{~mL}$ dimethylformamide. Appropriate amount of IL was added. Mixture was stirred for $1 \mathrm{~h}$ at $100{ }^{\circ} \mathrm{C}$, then cast onto Petri dish and dried for $24 \mathrm{~h}$ at $80^{\circ} \mathrm{C}$ to remove the solvent. Resulting membrane was peeled off and stored in closed plastic bag. 4 different composite membranes were prepared with IL content of 10 to $40 \mathrm{wt} \%$ in $10 \%$ increments for each IL, as well as pristine SPEEK reference membrane.

Mechanical properties were determined by strain-stress testing using Tinius Olsen 25ST universal testing machine. This particular instrument was equiped with an environmental chamber, allowing measurements at elevated temperatures. For each type of membrane at least 5 parallel samples with $5 \mathrm{~mm}$ width and $50 \mathrm{~mm}$ length were prepared and tested at several different temperatures in a range of 30 to $150{ }^{\circ} \mathrm{C}$ in increments of 30 degrees, and their thickness was measured before testing. Crosshead moving speed was set to $10 \mathrm{~mm} / \mathrm{min}$. Following parameters were assessed: the elastic modulus $E$ and the yield strain $\varepsilon_{y}$. Elastic modulus $E$ was computed from the slope of the linear initial part of the strain-stress plot. Yield strain was determined from appropriate point in the strain-stress plot.

Formulas for all components used are shown in Fig. 1.<smiles>CCOc1ccc(Oc2ccc(C(=O)c3ccc(CC)cc3)cc2)c(S(=O)(=O)O)c1</smiles>

a

c<smiles>Cn1cc[n+](C)c1</smiles><smiles>Cc1n(C)cc[n+]1C</smiles>

b<smiles>CCCCCCCCCCCCCCCC</smiles>

d
Fig. 1. Chemical structures of composite membrane components: a-sulfonated poly(ether ether ketone) (SPEEK); $\mathrm{b}$-1,2,3-dimethylimidazolium dimethylphosphate ([MMMIm] $\left.\left[\mathrm{Me}_{2} \mathrm{PO}_{4}\right]\right) ; \mathrm{c}$-1-hexyl-3-methylimidazolium dimethylphosphate ([HMIm] $\left[\mathrm{Me}_{2} \mathrm{PO}_{4}\right]$ ); d-1-dodecyl-3-methylimidazolium dimethylphosphate ([DDMIm] $\left.\left[\mathrm{Me}_{2} \mathrm{PO}_{4}\right]\right)$

\section{RESULTS AND DISCUSSION}

In 2011 U.S. Department of Energy have set a guideline of $120{ }^{\circ} \mathrm{C}$ and $50 \%$ relative humidity as target operating conditions of PEM in automotive applications [3]. Nafion membrane at these conditions becomes soft and not suitable for its task [21-23]. It should be taken into account that our experiments were done in room atmosphere, that is, around $50 \%$ relative humidity (at room temperature), thus some absorbed water in the tested membranes are to be expected.

Experimental values of elastic modulus for all prepared membranes are shown in Fig. 2. At $150{ }^{\circ} \mathrm{C}$ all membranes, including the pristine SPEEK membrane, have lost their structural strength, meaning that after start of the experiment, plastic deformation stage begins almost immediately. Thus the temperature of $120^{\circ} \mathrm{C}$ can be considered an upper limit at which some of these samples retain mechanical strength suitable for use in pressurized environment. If we assume that sufficient value of elastic modulus for these membranes should be around $100 \mathrm{MPa}$ (Fig. 2., dashed red line), then upper limit of IL content for each type of composite membrane at particular temperature can be determined. In worst case scenario for $[\mathrm{MMMIm}]\left[\mathrm{Me}_{2} \mathrm{PO}_{4}\right] /$ SPEEK composite membrane at $120{ }^{\circ} \mathrm{C}$ this limit is 0 wt.\% IL content (Fig. 2 a) - that is, this particular composite membrane is not suitable for operation at $120{ }^{\circ} \mathrm{C}$.

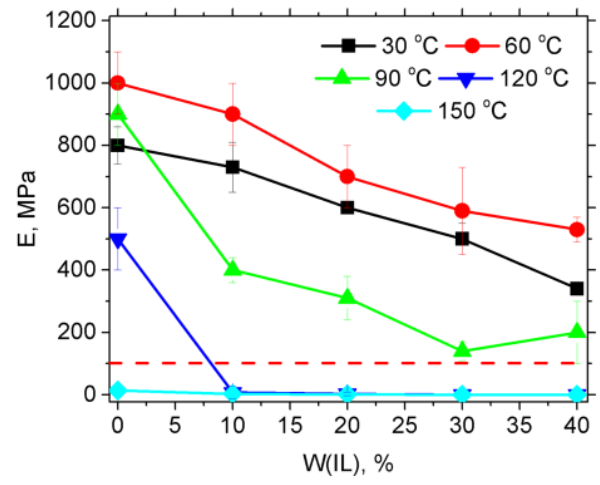

a

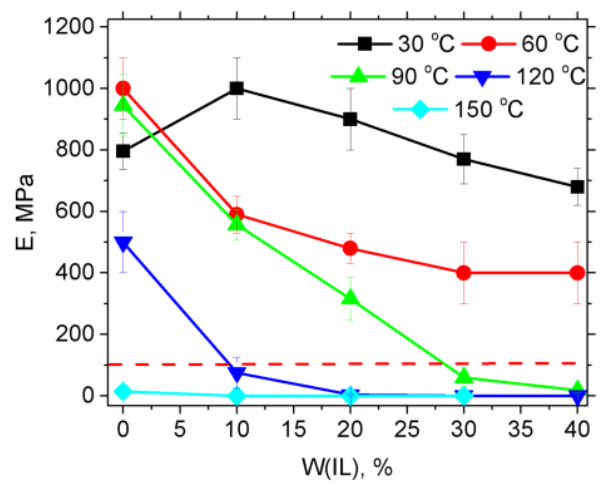

b

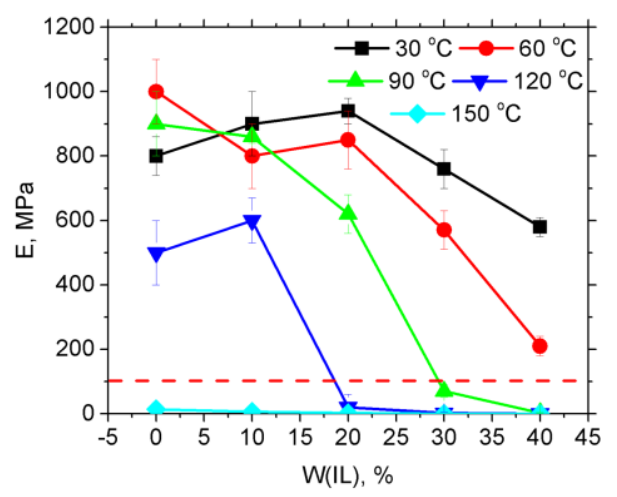

c

Fig. 2. Elastic modulus depending on IL content at various temperatures for: $\mathrm{a}-[\mathrm{MMMIm}]\left[\mathrm{Me}_{2} \mathrm{PO}_{4}\right] / \mathrm{SPEEK}$; $\mathrm{b}-[\mathrm{HMIm}]\left[\mathrm{Me}_{2} \mathrm{PO}_{4}\right] / \mathrm{SPEEK} ; \quad \mathrm{c}-[\mathrm{DDMIm}]\left[\mathrm{Me}_{2} \mathrm{PO}_{4}\right] / \mathrm{SPEEK}$ composites 
Between different IL composites certain patterns of differences can be seen. As the length of carbon chain in IL increases from $1 \mathrm{C}$ atom in $[\mathrm{MMMIm}]\left[\mathrm{Me}_{2} \mathrm{PO}_{4}\right]$ to $12 \mathrm{C}$ atoms in $[\mathrm{DDMIm}]\left[\mathrm{Me}_{2} \mathrm{PO}_{4}\right]$, rate at which $\mathrm{E}$ value decreases when raising IL content is increasing. This can be explained by the intensification of plasticizer effect of ILs as their molecular size grows with increasing carbon chain length.

Presence of $[\mathrm{DDMIm}]\left[\mathrm{Me}_{2} \mathrm{PO}_{4}\right]$ (the green line in Fig. 3) seem to have more positive impact on elastic modulus at lower IL content while the opposite is true at higher content of this IL.

This is similar to a lesser extent with [HMIm] $\left[\mathrm{Me}_{2} \mathrm{PO}_{4}\right]$. In other words, as the size of IL molecular structure increases, influence of IL content seems to overcome the influence of temperature, confirming that increasing carbon chain length correlates with increased plasticizer effect on an IL in IL/SPEEK composite membrane.
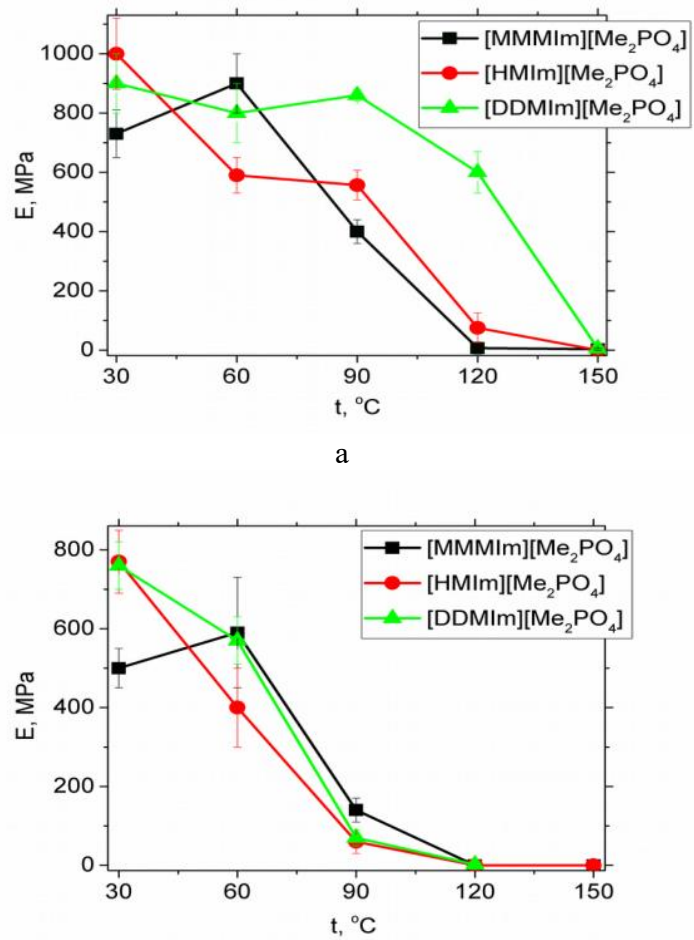

c
The progression of shape of strain-stress curves when increasing IL content can be observed in Fig. 4.

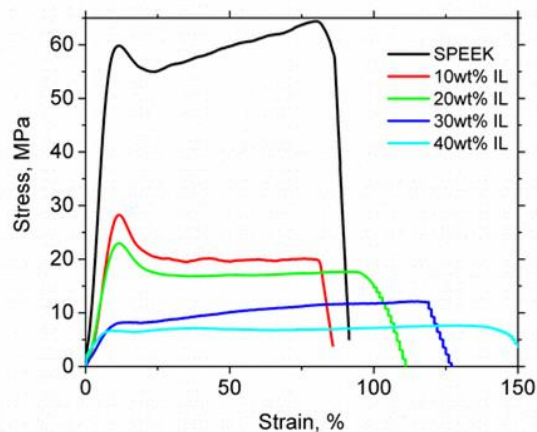

Fig. 4. Typical stress-strain curves for IL/SPEEK composites at $90{ }^{\circ} \mathrm{C}$

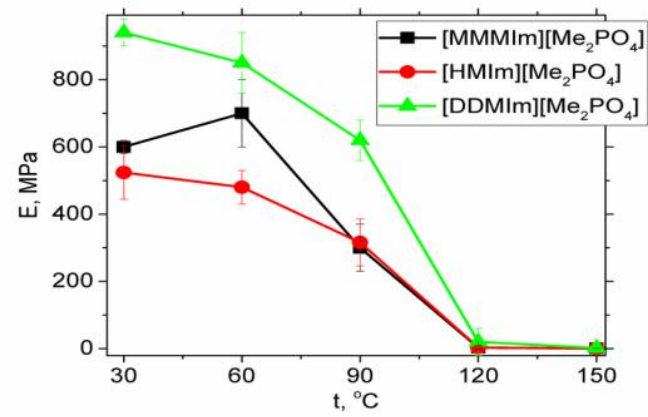

$\mathrm{b}$

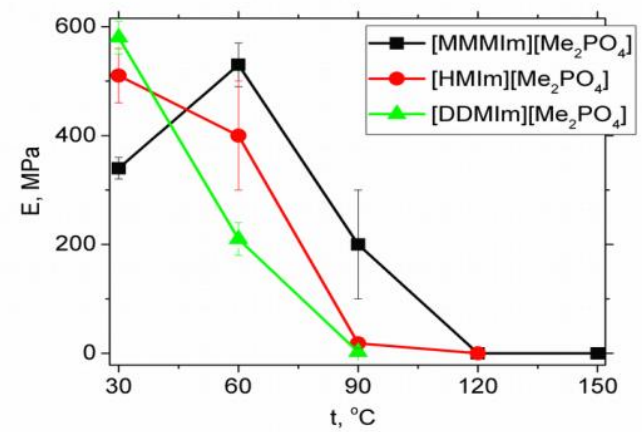

d

Fig. 3. Elastic modulus depending on temperature for IL content: a - 10 wt. $\%$; b -20 wt. $\%$; c-30 wt.\%; d-40 wt. \%

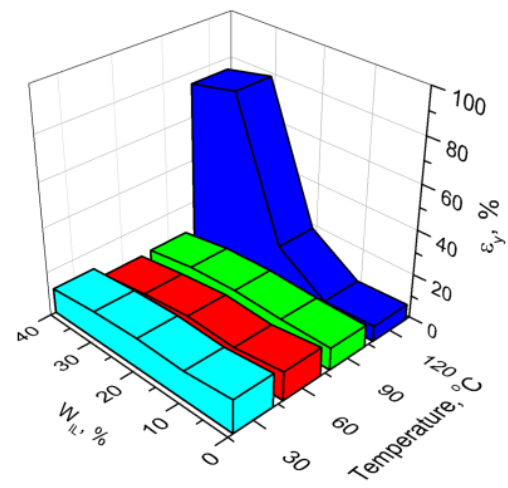

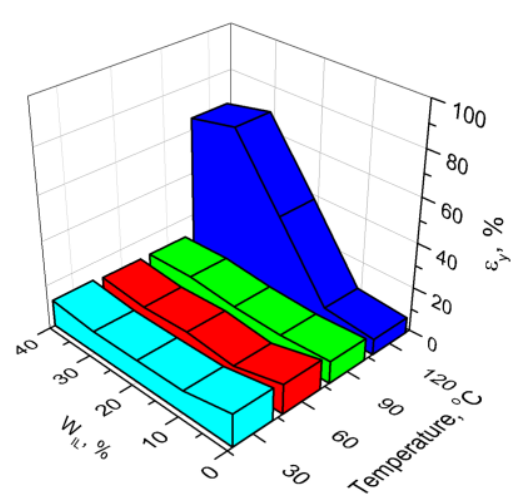

b

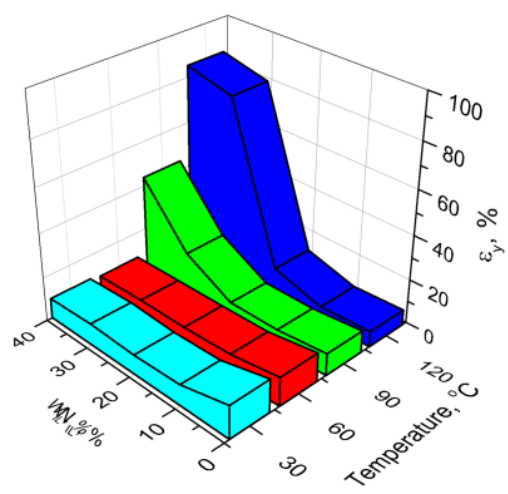

c

Fig. 5. Yield strain $\varepsilon_{y}$ as a function of IL content at various temperatures for SPEEK-IL composite membranes containing: $\mathrm{a}-[\mathrm{MMMIm}]\left[\mathrm{Me}_{2} \mathrm{PO}_{4}\right] ; \mathrm{b}-[\mathrm{HMIm}]\left[\mathrm{Me}_{2} \mathrm{PO}_{4}\right] ; \mathrm{c}-[\mathrm{DDMIm}]\left[\mathrm{Me}_{2} \mathrm{PO}_{4}\right]$ 
The characteristic neck-forming during deformation in case of SPEEK membrane points out the partially crystallic nature of this sample. As IL content is increased to $40 \mathrm{wt} . \%$, plastic deformation becomes dominant, due to weakening of interaction forces between individual SPEEK polymer chains.

Since the membrane in PEMFC is under constant pressure changes in dimensional stability of PEM during operation of FC are possible - but undesirable, as the risk of mechanical damage to the membrane increases. Yield strain $\left(\varepsilon_{\mathrm{y}}\right)$ was determined from stress-strain curves and it shows degree of elongation at yield stress - after this point material undergoes irreversible deformation. Yield strain depending on IL content at various temperatures is shown in Fig. 5. It was determined that up until $120{ }^{\circ} \mathrm{C}$ yield strain remained in a range of about $10-15 \%$ for all samples meaning that degree of dimensional deformation at these conditions is rather low at this temperature range for tested samples. An exception to this observation was composite containing an IL with longest attached carbon chain $[\mathrm{DDMIm}]\left[\mathrm{Me}_{2} \mathrm{PO}_{4}\right]$, as it showed increased deformation starting at $90{ }^{\circ} \mathrm{C}$.

\section{CONCLUSIONS}

Membranes synthesized in this work were found to be suitable for operation at up to $120^{\circ} \mathrm{C}$ for some composites. While not usable in the entire HT PEMFC range the tested composite membranes show some promise. Results show that the structure of IL has impact on the mechanical properties of the membranes, with [DDMIm] $\left[\mathrm{Me}_{2} \mathrm{PO}_{4}\right]$ having the most pronounced plasticizer effect due to its molecular size. It was found that strain values in the previously determined useable operating temperature range were confined to approx $10-20 \%$.

\section{Acknowledgments}

This work was supported by Latvian Council of Science (Cooperation project No.666/2014.4).

\section{REFERENCES}

1. Cook, J., Oreskes, N., Doran, P.T., Anderegg, W.R.L., Verheggen, B., Maibach, E.W., Carlton, J.S., Lewandowsky, S., Skuce, A.G., Green, S.A., Nuccitelli, D., Jacobs, P., Richardson, M., Winkler, B., Painting, R., Rice, K. Consensus on Consensus: A Synthesis of Consensus Estimates on Human-Caused Global Warming Environmental Research Letters 11 (4) 2016: pp. 048002. http://dx.doi.org/10.1088/1748-9326/11/4/048002

2. Kraytsberg, A., Ein-Eli, Y. Review of Advanced Materials for Proton Exchange Membrane Fuel Cells Energy \& Fuels 28 (12) 2014: pp. 7303-7330.

http://dx.doi.org/10.1021/ef501977k

3. Tripathi, B.P., Shahi, V.K. Organic-inorganic Nanocomposite Polymer Electrolyte Membranes for Fuel Cell Applications Progress in Polymer Science $36(7)$ 2011: pp. $945-979$.

http://dx.doi.org/10.1016/j.progpolymsci.2010.12.005.

4. Rangasamy, V. S., Thayumanasundaram, S., Seo, J. W., Locquet, J.-P. Vibrational Spectroscopic Study of Pure and Silica-Doped Sulfonated Poly(Ether Ether Ketone) Membranes Spectrochimica Acta Part A: Molecular and Biomolecular Spectroscopy 138 2015: pp. 693-699. http://dx.doi.org/10.1016/j.saa.2014.12.004

5. Wu, L., Zhang, Z., Ran, J., Zhou, D., Li, C., Xu, T. Advances in Proton-Exchange Membranes for Fuel Cells: An Overview on Proton Conductive Channels (PCCs) Physical Chemistry Chemical Physics 15 (14) 2013: pp. 4870-4887. http://dx.doi.org/10.1039/C3CP50296A

6. Peighambardoust, S.J., Rowshanzamir, S., Amjadi, M. Review of the Proton Exchange Membranes for Fuel Cell Applications International Journal of Hydrogen Energy 35 (17) 2010: pp. 9349 - 9384.

http://dx.doi.org/10.1016/j.ijhydene.2010.05.017

7. Jarumaneeroj, C., Tashiro, K., Chirachanchai, S. Molecular Mobility of Imidazoles in Molten State as a Key Factor to Enhance Proton Conductivity Journal of Power Sources 249 2014: pp. 185-192.

http://dx.doi.org/10.1016/j.jpowsour.2013.10.126.

8. Díaz, M., Ortiz, A., Vilas, M., Tojo, E., Ortiz, I. Performance of PEMFC with New Polyvinyl-Ionic Liquids Based Membranes as Electrolytes International Journal of Hydrogen Energy 39 (8) 2014: pp. 3970-3977. http://dx.doi.org/10.1016/j.ijhydene.2013.04.155

9. Hou, H., Di Vona, M.L., Knauth, P. Building Bridges: Crosslinking of Sulfonated Aromatic Polymers - A Review Journal of Membrane Science 423-424 2012: pp. $113-127$. http://dx.doi.org/10.1016/j.memsci.2012.07.038.

10. Iulianelli, A., Basile, A. Sulfonated PEEK-Based Polymers in PEMFC and DMFC Applications: A Review International Journal of Hydrogen Energy 37 (20) 2012: pp. $15241-15255$. http://dx.doi.org/10.1016/j.jihydene.2012.07.063.

11. Zhang, H., Wu, W., Wang, J., Zhang, T., Shi, B., Liu, J., Cao, S. Enhanced Anhydrous Proton Conductivity of Polymer Electrolyte Membrane Enabled by Facile Ionic Liquid-Based Hoping Pathways Journal of Membrane Science 476 2015: pp. 136-147. http://dx.doi.org/10.1016/j.memsci.2014.11.033.

12. Zhang, H., Wu, W., Li, Y., Liu, Y., Wang, J., Zhang, B., Liu, J. Polyelectrolyte Microcapsules as Ionic Liquid Reservoirs within Ionomer Membrane to Confer High Anhydrous Proton Conductivity Journal of Power Sources 279 2015: pp. 667-677. http://dx.doi.org/10.1016/j.jpowsour.2015.01.066

13. Arias, J.J.R., Carlos Dutra, J., Gomes, A. de S. Hybrid Membranes of Sulfonated Poly Ether Ether Ketone, Ionic Liquid and Organically Modified Montmorillonite for Proton Exchange Membranes with Enhanced Ionic Conductivity and Ionic Liquid Lixiviation Protection Journal of Membrane Science 537 2017: pp. 353-361. http://dx.doi.org/10.1016/j.memsci.2017.05.044

14. He, Z., Alexandridis, P. Ionic Liquid and Nanoparticle Hybrid Systems: Emerging Applications Advances in Colloid and Interface Science 244 2017: pp. 54-70. http://dx.doi.org/10.1016/j.cis.2016.08.004

15. Da Trindade, L.G., Zanchet, L., Padilha, J.C., Celso, F., Mikhailenko, S.D., $\quad$ Becker, M.R., de Souza, M.O., de Souza, R.F. Influence of Ionic Liquids on the Properties of Sulfonated Polymer Membranes Materials Chemistry and Physics 148 (3) 2014: pp. 648-654. http://dx.doi.org/10.1016/j.matchemphys.2014.08.030

16. Scott, M.P., Rahman, M., Brazel, C.S. Application of Ionic Liquids as Low-Volatility Plasticizers for PMMA European Polymer Journal 39 (10) 2003: pp. 1947-1953. http://dx.doi.org/10.1016/S0014-3057(03)00129-0

17. Malik, R.S., Tripathi, S.N., Gupta, D., Choudhary, V. 
Novel Anhydrous Composite Membranes Based on Sulfonated Poly (Ether Ketone) and Aprotic Ionic Liquids for High Temperature Polymer Electrolyte Membranes for Fuel Cell Applications International Journal of Hydrogen Energy 39 (24) 2014: pp. 12826-12834.

http://dx.doi.org/10.1016/j.ijhydene.2014.06.060

18. Yi, S., Zhang, F., Li, W., Huang, C., Zhang, H., Pan, M. Anhydrous Elevated-Temperature Polymer Electrolyte Membranes Based on Ionic Liquids Journal of Membrane Science $366(1-2)$ 2011: pp. 349-355.

http://dx.doi.org/10.1016/j.memsci.2010.10.031.
19. Zhang, W., Gogel, V., Friedrich, K.A., Kerres, J. Novel Covalently Cross-Linked Poly(Etheretherketone) Ionomer Membranes Journal of Power Sources $155(1)$ 2006: pp. $3-12$.

http://dx.doi.org/10.1016/j.jpowsour.2004.12.082

20. Brica, S., Freimane, L., Kulikovska, L., Zicmanis, A. N,N'-Dialkylimidazolium Dimethyl Phosphates - Promising Media and Catalysts at the Same Time for Condensation Reactions Chemical Science International Journal 19 (4) 2017: pp. $1-9$.

http://dx.doi.org/10.9734/CSJI/2017/34482 